\title{
Study of animal remains dug out during the excavations of a Nuragic village in Sardinia
}

\author{
Laura Portas, ${ }^{1}$ Stefania Bagella, ${ }^{2}$ Vittorio Farina, ${ }^{1}$ Marcella Carcupino, ${ }^{3}$ Antonio Cacchioli, ${ }^{4}$ \\ Ferdinando Gazza, ${ }^{4}$ Marco Zedda ${ }^{1}$ \\ ${ }^{1}$ Department of Veterinary Medicine, University of Sassari; ${ }^{2}$ Sciences Museum, University of Sassari; \\ ${ }^{3}$ Department of Nature and Territory Sciences, University of Sassari, Sassari; ${ }^{4}$ Department of \\ Veterinary Medicine, University of Parma, Parma, Italy
}

\begin{abstract}
This paper presents the results of the zooarchaeological analysis of the faunal materials brought to light during the excavations set up in the Nuragic village surrounding the Santu Antine Nuraghe, near Torralba (Sassari), Sardinia. Precisely, the remains come from the structure of the village named by archaeologists hut 12 . They are 779 specimens out of thousands animal remains from the whole archaeological site. The majority of the rests belong to sheep (Ovis aries) or goats (Capra hircus), cattle (Bos taurus), pigs (Sus scrofa) and deers (Cervus elaphus). Such material may provide suggestions about the productive use of animals in the village and point out the importance of the economical management of animals in the Nuragic society.
\end{abstract}

Correspondence: Marco Zedda, Department of Veterinary Medicine, University of Sassari, via Vienna 2, 07100 Sassari, Italy.

Tel. +39.079.229583 - Fax +39.079.229432.

E-mail: mzedda@uniss.it

Key words: Animal remains; Archaeological excavations; Nuragic settlement; Sardinia.

Contributions: SB directed the archaeological excavations and gave the material its specific historical context; MZ and FG conceived and designed the research and interpreted the data; LP and MC analyzed samples and drafted the article; $\mathrm{VF}$ and $\mathrm{AC}$ revised the text critically and approved the final version.

Conflict of interest: the authors declare no potential conflict of interest.

Funding: work supported by the Fondazione Banco di Sardegna.

Received for publication: 17 September 2015.

Revision received: 25 November 2015.

Accepted for publication: 16 December 2015.

(C) Copyright L. Portas et al., 2015

Licensee PAGEPress, Italy

Journal of Biological Research 2015; 88:5523

doi:10.4081/jbr.2015.5523

This article is distributed under the terms of the Creative Commons Attribution Noncommercial License (by-nc 3.0) which permits any noncommercial use, distribution, and reproduction in any medium, provided the original author(s) and source are credited.
Indeed, many remains show signs with human origin, which testify that the hut may have been a workplace where bone fragments were processed to obtain different kind of tools.

\section{Introduction}

The Nuragic civilization took place in Sardinia during the Bronze and Iron Age (18 $8^{\text {th }}-6^{\text {th }}$ century BC) and is characterized by megalithic structures known as nuraghi, the ruins of which are nowadays about 8 thousands everywhere in the island.

The nuraghe of Santu Antine ( $40^{\circ} 29^{\prime} 12.29^{\prime \prime}$ N - $8^{\circ} 46^{\prime} 10.42$ ”E) is located near Torralba (Sassari), in the Cabu Abbas plain. Its structure, one of the most complex in Sardinia, is massive and consists of a central tower, a triangular rampart and, inside, three towers linked by corridors, stairs and bastions. The name Santu Antine, as suggested by Valery, ${ }^{1}$ comes from the Turritan Judge Costantino I or II $\left(11^{\text {th }}\right.$. $12^{\text {th }}$ century $\mathrm{AD}$ ), as the nuraghe has been erroneously considered his sepulchral monument by local populations. This interpretation also justifies its second denomination, Sa Domo de su Re, i.e. the King's house in Sardinian language. ${ }^{2}$ The nuraghe of Santu Antine offers the possibility to study a part of the history of Nuragic civilization through the analysis of new elements and new anthropic evidences. The excavations around this area have indeed revealed a Nuragic village consisting of circular huts.

The archaeological excavations in the surrounding area began in 1935, and revealed the existence of a large Nuragic village, mainly consisting of ruins of circular huts, as well as a series of buildings of the Roman Age, recognizable for the peculiarity of their rectangular plan.

A new excavation campaign conducted in 2003-2004 in the Western part of the Nuragic village dug out three circular huts, named hut 12,13 and 14 . These are about 10 meters from the rampart. All around, a significant number of flat stones regularly arranged and leveled could be interpreted as a first attempt to organize outdoor spaces, i.e. the paving of the way for a connection among huts. ${ }^{3}$

This paper presents the results of the analysis of the animal remains found during several excavation campaigns in the hut 12 , sector 1000 (1029, 1037 and 1042 stratigraphical units) with the purpose of providing additional guidelines on the habits of that Nuragic village and contributing to the protohistorical and anthropological reconstruction of the Nuragic society. The hut 12 dates back to the Late Bronze Age and an early stage of Iron Age. The anatomical study on the faunal material found out has the purpose to trace back to the specific bones, species and age of death of the animals in the Nuragic village. 


\section{Materials and Methods}

During the numerous excavation campaigns of the Nuraghe Santu Antine thousands animal remains were found, which are for the most part fragmented bones, a lot of them showing evident human signs.

The material belonging to the hut 12 has been analyzed, cataloged, signed, photographed and carefully stored.

Before starting the analysis, cleaning of earthy encrustations was made by washing carefully, brushing with a soft brush and leaving to dry for at least 48 hours. Dental finds were brushed only. The analysis started first with the observation of the bones, in order to find pieces that fitted together and could be assembled; in those cases they were glued with vinyl glue, to reconstruct body parts. Then, zooarchaeological analysis proceeded following the steps, according to current techniques of study: i) recognition of the anatomical part (skull, vertebrae, ribs, limb bones), species and, when possible, sex; ii) estimation of the age of death; iii) analysis of human marks (slaughtering and/or processing); iv) osteometric study; v) photographic documentation of the most significant findings.

\section{Recognition of anatomical parts, species and sex}

For the morphological study, the osteological collection of the Section of Anatomy at the Department of Veterinary Medicine, University of Sassari, was taken as reference. The species identification was also supported by the consultation of specific detailed studies. They take into account for the distinction between sheep and goats, ${ }^{4-6}$ between pigs and wild boars, ${ }^{7}$ and among cervids. ${ }^{8}$ Sex determination was attempted on the base of coxal bone morphology, following what reported in the literature, such as Hatting for sheep. ${ }^{9}$

\section{Age of death}

The estimation of the age of death was based on the analysis of growth plates in long bones, in agreement with what reported by Barone. ${ }^{10}$ As to teeth, a useful element was the tooth wear stages. ${ }^{11}$

\section{Analysis of human marks}

The remains showing clear marks of taphonomic processes were separated, and, in a second time, bone fragments showing human marks were distinguished, excluding the signs of bites of carnivores, ruts from rodents' incisors, signs and fractures due to natural factors or recent signs left during the excavations.

\section{Osteometrical study}

When bones were intact, measurements were taken according to von den Driesch. ${ }^{12}$ On the base of those data, the withers height was calculated following May et al. for pigs, ${ }^{13}$ Teichert ${ }^{14}$ for sheep and Schramm ${ }^{15}$ for goats.

\section{Results}

The total number of the bone remains found in the hut 12 is 779 , with a weight of about $4.4 \mathrm{~kg}$. The $44 \%$ of them belongs to a defined species, while the rest is unidentified.

In the group of the determined bones, the highest number belongs to the sheep and goat (64\%), followed by pig (16\%), cattle (15\%) and deer (5\%). Number and percentage of identified and unidentified remains are reported in Table 1 . In addition to the bones, 26 animal teeth were found. They belong to the same species, which the described bones come from.

Osteometric data are based on the parameters suggested by von den Driesch. ${ }^{12}$ Since the high degree of fragmentation involved almost all the long bones, the results are based on astragalus and calcaneus bones and in few cases on radius and metacarpal/metatarsal bones (Table 2). From five swine bones and six sheep/goat bones the wither height was calculated. In details, it was $52 \mathrm{~cm}$ for pigs, $51 \mathrm{~cm}$ for sheep/goats and $47.3 \mathrm{~cm}$ for sheep on average.

\section{Discussion}

The high fragmentation made it possible to recognize the species in almost half of the remains. On the other hand, such high degree of fragmentation is of some interest, as may be suggestive of slaughtering and processing activities in the area of the archaeological site.

The presence of domestic species is significantly higher than the wild ones, suggesting that breeding was the main activity in the village, whereas hunting was practiced sporadically.

The main difficulties in species determination were encountered in distinguishing between sheep and goats, because of their high similarity, so, when it was not possible to distinguish them, remains were combined in a general taxonomic category sheep/goats as Ovis vel

Table 1. Identified and unidentified bone remains belonging to different anatomical regions of cow, sheep and goat, pig and reed.

\begin{tabular}{|c|c|c|c|c|c|c|}
\hline \multirow[t]{2}{*}{ Remains } & \multicolumn{2}{|c|}{ Identified (n=341) } & \multicolumn{2}{|c|}{ Unidentified ( $\mathrm{n}=438$ ) } & \multicolumn{2}{|c|}{ Total (n=779) } \\
\hline & BOS & OVC & SUS & CERVUS & n & $\%$ \\
\hline Skull & 8 & 6 & 5 & 0 & 19 & 14 \\
\hline Teeth & 3 & 7 & 14 & 2 & 26 & 20 \\
\hline Thorax, rachis, pelvis & 32 & 136 & 4 & 3 & 175 & 39 \\
\hline Shoulder & 3 & 10 & 1 & 1 & 15 & 3 \\
\hline Arm & 3 & 7 & 6 & 0 & 16 & 4 \\
\hline Forearm & 0 & 11 & 0 & 1 & 12 & 3 \\
\hline Hand-foot & 2 & 18 & 15 & 6 & 41 & 9 \\
\hline Thigh & 1 & 17 & 3 & 0 & 21 & 4 \\
\hline Leg & 1 & 7 & 5 & 3 & 16 & 4 \\
\hline Total & 53 & 219 & 53 & 16 & 341 & 100 \\
\hline
\end{tabular}

BOS, cow; OVC, sheep and goat; SUS, pig; CERVUS, reed. 
Capra was used. Due to the high degree of fragmentation, the distinction between domestic pigs and wild boars was not possible, so their remains were classified with the general term of pig (Sus). It could not be excluded that Nuragic pigs were bred in semi-wild conditions and crosses between domestic and wild pigs frequently occurred.

As to the age of death, a distinction was made between young and adult animals. As is well-known, this distinction is useful to understand the breeding techniques. Indeed, the prevalence of animals butchered when subadults means that the most practiced activity was meat production, whereas remains from adults suggest that they were used for reproduction, workforce (cattle) and dairy (cows, sheep and goats).

The most part of our remains belonged to adult animals (90\%). The reduced amount of juvenile bones was from pig and Ovis vel Capra only, suggesting that these species were bred for meat production, whereas cattle were probably butchered when adults after their exploitation for work. The remains from thorax are in a high percentage because of the numerous rib fragments. Other significant percentages are those of limb long bones and also flat bones, such as s houlder and skull (Table 1). In this regard, it can be hypothesized that parts of the body normally cut and thrown away as slaughter wastes, were brought into the hut to undergo handcraft activities. For instance, metacarpal and metatarsal bones, which were very numerous, were probably used for the production of tools such as cutting tips.

The frequent finding of transversal clear cuts between epiphysis and diaphysis in long bones such as humerus, radius, femur, tibia, metacarpal and metatarsal bones would suggest a standard procedure aimed at separating diaphyses (Figure 1).

In addition, some isolated diaphyses were subdivided into two lon-

Table 2. Osteometric data based on von den Driesch parameters. ${ }^{12}$

\begin{tabular}{|c|c|c|c|c|c|c|c|c|c|c|c|c|}
\hline \multirow[t]{2}{*}{ Animals } & \multirow[t]{2}{*}{ Anatomical region } & \multicolumn{11}{|c|}{ Parameters } \\
\hline & & Вp & Bd & Glpe & SD & GL & GLm & Dl & Dm & GL & B & GB \\
\hline Bos & First phalanx & 25.4 & 24.7 & 56.2 & 23.1 & & & & & & & \\
\hline Cervus & Astragalus & & 26.6 & & & 42.2 & 39.0 & 22.5 & 23.4 & & & \\
\hline \multirow[t]{6}{*}{ Sus } & III Metacarpal & 16.4 & 15.0 & & & & & & & 55.3 & 13.7 & \\
\hline & Astragalus & & & & & 36.6 & 33.4 & & & 21.5 & & \\
\hline & Astragalus & & & & & 39.0 & 35.8 & & & 23.3 & & \\
\hline & Calcaneus & & & & & & & & & 65.1 & & 21.7 \\
\hline & Calcaneus & & & & & & & & & 66.5 & & 22.2 \\
\hline & V Metatarsal & & 8.2 & & & & & & & 51.4 & & \\
\hline \multirow[t]{3}{*}{ Ovis aries } & Astragalus & & & & & 32.6 & 28.1 & 19.9 & 18.4 & 18.0 & & \\
\hline & Astragalus & & & & & 24.7 & 23.5 & & & 14.5 & & \\
\hline & Calcaneus & & & & & & & & & 61.3 & & 21.3 \\
\hline \multirow[t]{3}{*}{ Ovis vel Capra } & Radius & 29.7 & 24.5 & $\nabla$ & 16.3 & & & & & 136.1 & & \\
\hline & Calcaneus & & & & & & & & & 54.0 & & 19.8 \\
\hline & Calcaneus & & & & & & & & & 42.8 & & 14.3 \\
\hline
\end{tabular}

Bp, greatest breadth of the proximal end; Bd, greatest breadth of the distal end; Glpe, greatest length of the peripheral (abaxial) half; SD, smallest breadth of the diaphysis; GLl, greatest length of the lateral part; GLm, greatest length of the medial part; Dl, greatest depth of the lateral half; Dm, greatest depth of the medial half; GL, greatest length; B, breadth in the middle of the diaphysis; GB, greatest breadth. Measurements are expressed in millimeters.

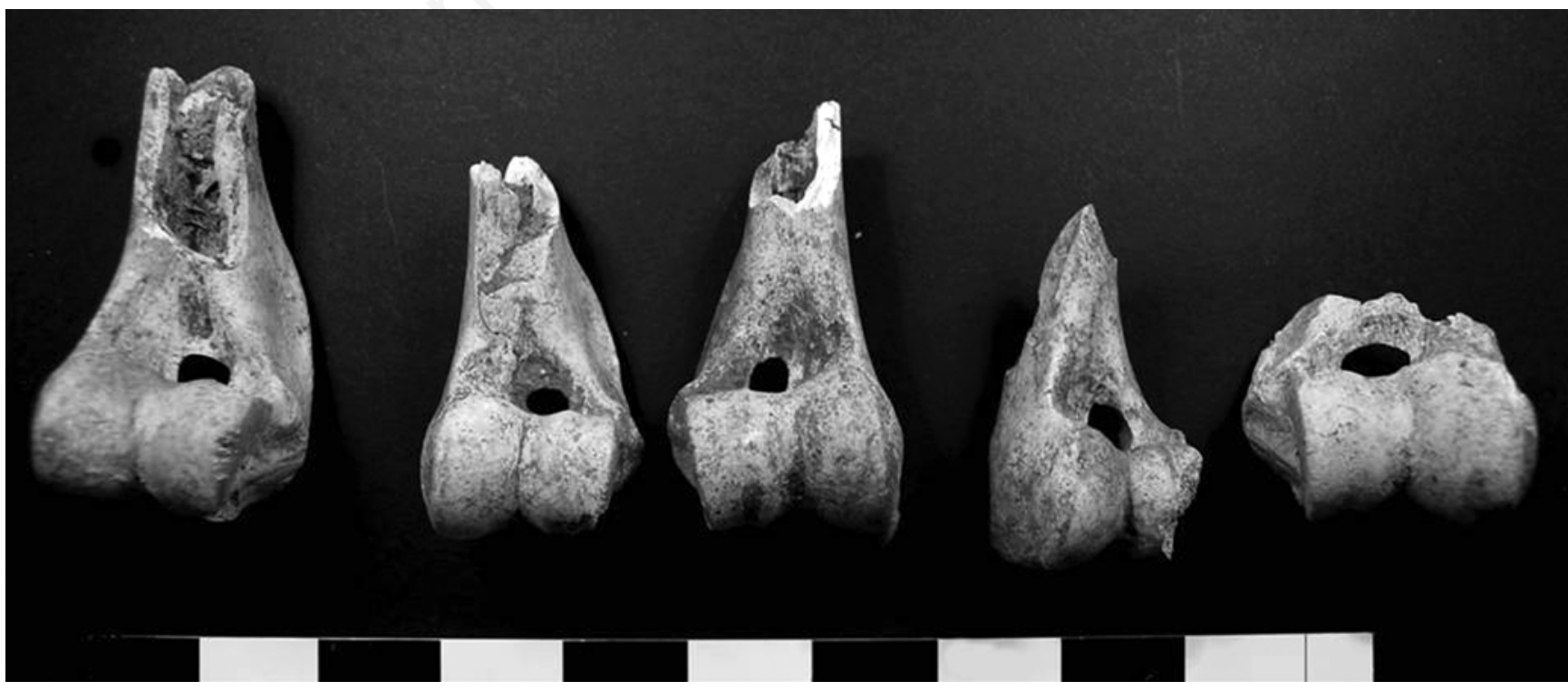

Figure 1. Distal segments of swine humeri intentionally broken to isolate the diaphysis. 


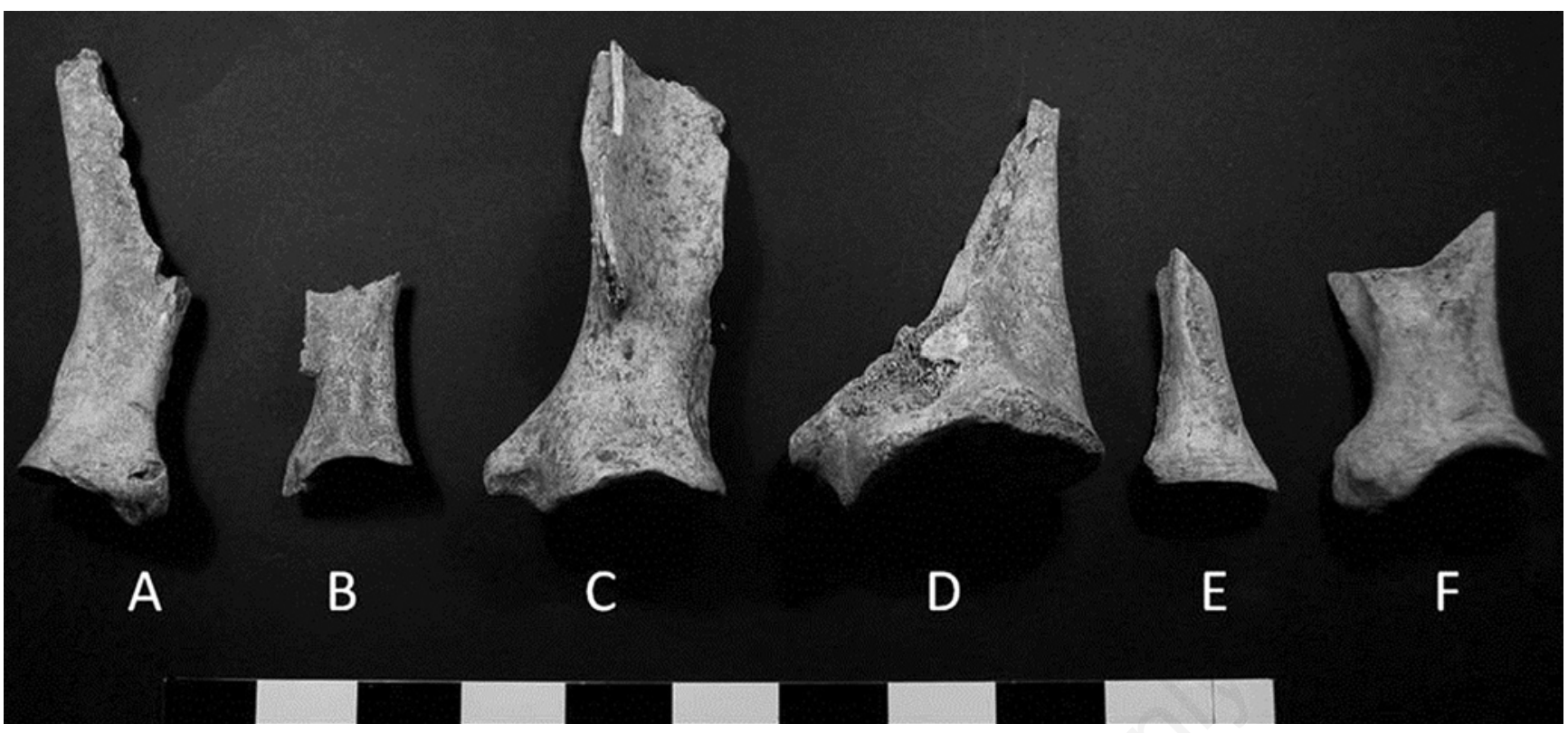

Figure 2. Comparison among distal ends of scapulae: sheep (A, B, E), deer (C), cattle (D) and pig (F). Note that all the scapulae show a similar clear cut of the distal epiphysis.

gitudinal halves to be further cut to obtain pointed splinters. Indeed, some of the fragments found in the hut show a pointed shape. Such kind of tools made of bone were very frequent in Mediterranean Bronze Age settlements. ${ }^{16}$

Even flat bones were used for creating tools and the most frequent technique attested in this site was the clear cut of the articular portion of the scapulae (Figure 2).

In major joints, such as shoulder, elbow, hip and knee joints, wellevident human marks were frequently noted, probably due to heavy cutting tools used for disarticulation. Another kind of light and superficial marks was found, probably made during the slaughtering process, to remove flesh from bones.

The wither height in pigs $(52 \mathrm{~cm})$ is rather lower than that found for this species in other Nuragic settlements, such as Nuraghe Arrubiu, Orroli $(70 \mathrm{~cm})$, as reported by Fonzo ${ }^{17}$ and Sant'Imbenia, Alghero (61$81 \mathrm{~cm})$, as reported by Manconi, ${ }^{18}$ so this might confirm the prevalence of subadults among slaughtered animals. Like in pigs, the mean withers height of sheep/goats $(51 \mathrm{~cm})$ is lower than the mean values obtained for sheep $(55 \mathrm{~cm})$ in the Nuragic village of Madonna del Rimedio, Oristano ${ }^{19}$ and in the same species $(58 \mathrm{~cm})$ in Serra Niedda, Sorso. ${ }^{20,21}$

Since no human marks were noted on the dental remains, the fact that their number is not as high as that of bones might confirm the hypothesis that the hut 12 was a place where handcraft activities on bones took place. This faunal assemblage is very different from that dug out in the northern tower of the Santu Antine Nuraghe, where animal remains have been exclusively interpreted as food remains. ${ }^{22}$

\section{Conclusions}

This study may provide suggestions about the productive use of animals in the village of Santu Antine and points out the importance of the economical management of animals in the Nuragic society. The majority of the rests belong to sheep (Ovis aries) or goats (Capra hircus), cattle (Bos taurus), pigs (Sus scrofa) and deers (Cervus elaphus). On account of the results reported, the hut 12 of the Nuragic village was a place where bones were processed in order to produce pointed or sharp instruments.

This idea could be confirmed by the presence within the hut of a round ceramic plate, a basalt pestle, two slickers and a lamp fragment, which may have been used for working, as well as a raised niche and some small cabinets suitable to storing up manufactured articles or keeping the working tools, as already suggested by archaeologists (Bagella and Cappai, 2012).

The bone remains do not show any burning signs, and in the area there are no traces of hotbeds. Their absence let us suppose that the hut 12 was not an area used for cooking, eating and throwing away food waste but it was exclusively used as a workplace. Moreover, bone fragments rejected during processing were probably used for paving.

The highest number of bone remains was from sheep and goats, but pigs and cattle were also well-represented. Though sporadically, deer hunting was practiced as well.

The prevalence of domestic animals among the species which the bone remains belong to, suggests that breeding was usually practiced in the village and it constituted the major subsistence activity.

\section{References}

1. Valery ACP. Voyages en Corse, à l'île d'Elbe et en Sardaigne. Paris, France: Bourgeois-Maze; 1837.

2. Moravetti A. Il nuraghe S. Antine nel Logudoro-Meilogu. Sassari, Italy: Carlo Delfino; 1988.

3. Bagella S, Cappai R. Le capanne 12, 13 e 14 del villaggio nuragico di Santu Antine (Torralba, SS). In: Proc. 44th Scientific Workshop: prehistory and protohistory of Sardinia. Florence, Italy: Nuove Grafiche Puddu; 2012. pp 1381-6. 
4. Boessneck J. Osteological differences between sheep (Ovis aries Linné) and goat (Capra hircus Linné). In: Brothwell DR, Higgs ES, eds. Science in archaeology: a comprehensive survey of progress and research. London, UK: Thames \& Hudson; 1969. pp 331-58.

5. Payne S. Morphological distinctions between the mandibular teeth of young sheep, Ovis, and goats, Capra. J Archaeol Sci 1985;12: $139-47$.

6. Zeder MA, Lapham HA. Assessing the reliability of criteria used to identify postcranial bones in sheep, Ovis, and goats, Capra. J Archaeol Sci 2010;37:2837-905.

7. Mayer JJ, Novak JM. Evaluation of molar size as a basis for distinguishing wild boar from domestic swine: employing the present to decipher the past. Available from: http:/works.bepress.com/james_ novak/21/

8. Lister A. The morphological distinction between bones and teeth of fallow deer (Dama dama) and red deer (Cervus elaphus). Int J Osteoarchaeol 1996;6:119-43.

9. Hatting T. Sex-related characters in the pelvic bone of domestic sheep (Ovis aries L.). Archaeofauna: Int J Archaezool 1995;4:71-6.

10. Barone R. Anatomia comparata dei mammiferi domestici. Bologna, Italy: Edagricole; 1976.

11. Grant A. The use of tooth wear as a guide to the age of domestic ungulates. In: Wilson B, Grigson C, Payne S, eds. Ageing and sexing animal bones from archaeological sites. Oxford, UK: British Archaeological Reports; 1982. pp 91-108.

12. Driesch von den A. A guide to the measurement of animal bones from archaeological sites. Harvard, UK: Harvard University; 1976.

13. May E, Teichert M, Hannama K. Allometric aspects to the determination of the withers height in pigs on the basis of the data of $\mathrm{M}$. Teichert. Archaeozoologia 1996;8:125-39.
14. Teichert M. Osteometrische Untersuchungen zur Berechnung der Widerristhöhe bei Schafen. In: Clason AT, ed. Archaeozoological studies. Amsterdam, The Netherlands: North-Holland Publishing Company/Elsevier; 1969. pp 51-69.

15. Schwramm Z. Morphological differences of some goat and sheep bones. Roczniki Wycszej Szkoly Rolniczej W Poznaniu 1967;36: 107-33.

16. De Grossi Mazzorin J. Artigiani dell'osso, avorio e palco. Ornamenti, utensili e giochi dalla preistoria al medioevo. Lecce, Italy: UniSalento Press; 2013.

17. Fonzo 0. La fauna nel nuraghe Arrubiu. In: Cossu T, Campus F, Leonelli V, Perra M, Sanges M, eds. La vita nel Nuraghe Arrubiu. Orroli, Italy: Grafica del Parteolla; 2003. pp 113-33.

18. Manconi F. La fauna dell'Età del Ferro degli scavi 1988 e 1990 del nuraghe S. Imbenia di Alghero (Sassari). In: Proc. 2nd National Congress on Archeozoology, Asti, 14-16 November 1997. Forlì, Italy: Abaco Edizioni; 2000. pp 267-77.

19. Santoni V, Wilkens B. Il complesso nuragico "La Madonna del Rimedio" di Oristano. Quaderni della Soprintendenza Archeologica di Cagliari-Oristano 1998;13:29-43.

20. Wilkens B. Resti rituali dal pozzo sacro di Serra Niedda (SS). In: Proc. 2nd National Congress on Archeozoology, Asti, 14-16 November 1997. Forlì, Italy: Abaco Edizioni; 2000. pp 263-66.

21. Wilkens B. Archeozoologia. Il Mediterraneo, la storia, la Sardegna. Sassari, Italy: Editrice Democratica Sarda; 2012.

22. Masala S. La fauna della torre Nord del Nuraghe Santu Antine tra la fine dell'età del Bronzo e il primo Ferro. Annali Univ Ferrara 2012;8:41. 